\title{
PERAN BADAN PENGAWAS PEMILIHAN UMUM KABUPATEN PAMEKASAN DALAM MENANGANI PELANGGARAN PEMILU 2019
}

\author{
Sukma Umbara Tirta Firdaus ${ }^{1}$; Syaiful Anam² \\ ${ }^{1,2}$ Prodi Administrasi Publik Fakultas Ilmu Administrasi Universitas Madura \\ Email: sukma1085@gmail.com; masanam.fiaunira@gmail.com
}

\begin{abstract}
Abstrak: Artikel ini memaparkan data-data tentang kinerja Bawaslu Kabupaten Pamekasan dalam menangani pelanggaran Pemilu 2019 di Kabupaten Pamekasan. Merupakan penelitian kualitatif dengan pendekatan diskriptif-kualitatif. Teknik sampling yang dilakukan purposive sampling. Hasil penelitian menunjukkan bahwa dalam menangani pelanggaran Pemilu, Bawaslu Kabupaten Pamekasan memiliki wewenang untuk menindaklanjuti pelanggaran dari dua sumber. Pertama, pelanggaran yang bersifat temuan, yaitu pelanggaran Pemilu yang ditemukan berdasarkan hasil pengawasan Bawaslu Kabupaten Pamekasan beserta jajarannya. Kedua, pelanggaran yang bersifat laporan, yaitu dugaan pelanggaran Pemilu yang dilaporkan masyarakat kepada Bawaslu Kabupaten Pamekasan dan jajarannya. Bawaslu Kabupaten Pamekasan telah mewujudkan keadilan dalam pelaksanaan Pemilu 2019 di Kabupaten Pamekasan. Pertama, ditertibkannya setiap APK melanggar di berbagai titik, mulai ukuran terkecil yang dipaku di pohon hingga ukuran terbesar yang dipasang Billboard berbayar. Kedua, semua temuan dan laporan ditangani secara professional berdasarkan aturan dan prosedur yang ada. Juga telah dilibatkannya rakyat Kabupaten Pamekasan secara aktif untuk ikut mengawasi setiap tahapan Pemilu 2019. Banyaknya laporan masyarakat (22 laporan) yang masuk ke Bawaslu Kabupaten Pamekasan, menunjukkan bahwa keterlibatan rakyat di Kabupaten Pamekasan sudah cukup bagus bersama-sama Bawaslu Kabupaten Pamekasan menciptakan keadilan Pemilu di Kabupaten Pamekasan.
\end{abstract}

Kata Kunci: Bawaslu Pamekasan; Pelanggaran; Pemilu 2019

Abstract: This article presents data on the performance of the Bawaslu Pamekasan Regency in handling violations of the 2019 Election in Pamekasan Regency. Qualitative research with a descriptive-qualitative approach. The sampling technique used was purposive sampling. The result showed that in handling election violations, Bawaslu Pamekasan Regency had the authority to follow up on violations from two sources. First, violations which are findings, namely election violations were found based on the results of supervision of the Bawaslu Pamekasan Regency and its staff. Second, reporting violations, namely alleged election violations reported by the public to the Bawaslu Pamekasan Regency and its staff. Bawaslu Pamekasan Regency had brought justice in the implementation of the 2019 Election in Pamekasan Regency. First, it disciplines each APK to break at various points, from the smallest size nailed to a tree to the largest size installed by a paid Billboard. Second, all findings and reports are handled professionally based on existing rules and procedures. The people of Pamekasan Regency are also actively involved in overseeing every stage of the 2019 elections. The large number of community reports (22 reports) that came to the Bawaslu of Pamekasan Regency, showed that community involvement in Pamekasan District was quite good together with the Bawaslu of Pamekasan Regency creating Election Justice in Pamekasan Regency.

Keywords: Bawaslu Pamekasan; Violations; Election 2019 
ISSN 2088-7469 (Paper) ISSN 2407-6864 (Online)

Volume 10 Nomor 2 (2020)

\section{PENDAHULUAN}

Sebagaimana amanat Undang-undang bahwa guna mencapai cita-cita bangsa dan tujuan nasional maka perlu diselenggarakan Pemilihan Umum (Pemilu) untuk memilih Presiden dan Wakil Presiden, anggota Dewan Perwakilan Rakyat (DPR), anggota Dewan Perwakilah Daerah (DPD), serta anggota Dewan Perwakilan Rakyat Daerah (DPRD) baik di tingkat provinsi maupun kabupaten/ kota seluruh Indonesia (Undang-Undang Pemilu, 2018: 1). Untuk pertamakalinya dalam sejarah Pemilu di Indonesia diadakan serentak pada 17 April 2019 lalu. Sistem Pemilu ini memberikan warna baru bagi perjalanan demokrasi Indonesia, dan menjadi pengalaman baru bagi setiap orang Indonesia, baik yang tinggal di dalam negeri maupun di luar negeri (Hermanto, dkk., 2020: 27). Sejak era reformasi, bangsa ini telah menggelar lima kali Pemilu, mulai 1999, 2004 merupakan awal diberlakukannya Pemilu Presiden-Wakil Presiden secara langsung, 2009, 2014, dan Pemilu serentak 2019 (Zuhro, 2019: 9).

Pelaksanaan Pemilu tersebut dilaksanakan oleh penyelenggara Pemilu, yang secara teknis diselenggarakan oleh sebuah komisi yang bersifat nasional yaitu Komisi Pemilihan Umum (KPU) Republik Indonesia. KPU memiliki jajaran hingga tingkat terbawah, mulai dari KPU Provinsi di tingkat provinsi, KPU Kabupaten/ Kota di tingkat kabupaten/ kota, Panitian Pemilihan Kecamatan (PPK) di tingkat kecamatan, Panitia Pemungutan Suara (PPS) di tingkat kelurahan/ desa, Kelompok Penyelenggara Pemungutan Suara (KPPS) di tingkat Tempat Pemungutan Suara (TPS), serta penyelenggara Pemilu teknis di luar negeri yang masih dalam koordinasi KPU RI. Tahapan-tahapan teknis hingga pelaksanaannya pada 17 April 2019 sudah dilakukan oleh KPU dan jajaran sejak satu tahun sebelumnya (UndangUndang Pemilu, 2018: 5-6).

Dalam rangka pelaksaan Pemilu ini, perlu sebuah pengawasan aktif dari negara guna mengantisipasiberbagai hal di dalam pelaksanaan Pemilu, terutama pontensi-potensi pelanggaran Pemilu atau bisa juga disebut potensi permasalahan hukum Pemilu (Alfiantoro, 2018, 137). Karena itu, negara telah membentuk satuan kerja untuk mengawasi Pemilu, sebuah badan yaitu Badan Pengawas Pemilu (Bawaslu) Republik Indonesia, yang juga bersifat nasional. Sama halnya dengan KPU, Bawaslu juga memiliki jajaran hingga tingkat TPS. Jajaran Bawaslu RI ada Bawaslu Provinsi untuk mengawasi pelaksanaan Pemilu di tingkat provinsi, kemudian Bawaslu Kabupaten/Kota untuk mengawasi pelaksanaan Pemilu di tingkat kabupaten/kota, kemudian Panitia Pengawas Pemilu Kecamtan (Panwaslu Kecamatan) untuk mengawasi pelaksanaan Pemilu di tingkat kecamatan, kemudian Panitia Pengawas Pemilu Kelurahan/Desa (Panwaslu Kelurahan/Desa) untuk mengawasi pelaksanaan Pemilu di tingkat kelurahan/ desa, Pengawas Tempat Pemungutan Suara (Pengawas TPS), hingga pengawas Pemilu di luar negeri yang juga masih dalam koordinasi Bawaslu RI. Berdasarkan Undang-undang Pemilu, ada hal menarik untuk dikaji yaitu berubahnya status Panita Pengawas Pemilu Kabupaten/Kota (Panwaslu Kabupaten/Kota) yang ad hoc menjadi Badan Pengawas Pemilu Kabupaten/Kota (Bawaslu Kabupaten/Kota) yang permanen dengan masa jabatan komisionernya lima tahun (Undang-Undang Pemilu, 2018: 6-7). 
Berangkat dari kebijakan ini, peneliti mencoba untuk mengetahui seperti apa sepak terjang Bawaslu Kabupaten Pamekasan, dalam mengawasi pelaksanaan Pemilu 2019 serentak untuk pertama kalinya dalam sejarah Pemilu Indonesia di Kabupaten Pamekasan (Sukmajati, 2019: 3). Mengingat, selain lembaga ini sudah dipermanenkan, juga wewenangnya semakin diperkuat dibandingkan ketika masih berstatus ad hoc. Sebagaimana tagline Bawaslu, "Bersama Rakyat Awasi Pemilu, Bersama Bawaslu Tegakkan Keadilan Pemilu". Apakah dengan kahadiran lembaga Bawaslu di Kabupaten Pamekasan ini, pelaksanaan Pemilu sejak awal hingga akhir di Kabupaten Pamekasan benar-benar terlaksana dengan adil? Dan apakah rakyat juga terlibat dalam mengawasi pelaksanaan Pemilu tersebut? Semua pertanyaan itu akan terjawab dalam tulisan ini.

\section{METODE PENELITIAN}

Kajian dalam tulisan ini adalah penelitian kualitatif dengan pendekatan diskriptifkualitatif (Moleong, 2015: 11). Peneliti ingin menyajikan data-data terkait kinerja Bawaslu Kabupaten Pamekasan dalam mengawasi pelaksanaan Pemilu di Kabupaten Pamekasan pada Tahun 2019, dimana hasil dari pengawasannya tersebut ditindaklanjuti dalam proses penanganan pelanggaran Pemilu 2019 oleh Bawaslu Kabupaten Pamekassan. Akan diuraikan seberapa banyak pelanggaran Pemilu 2019 yang terjadi di Kabupaten Pamekasan dan seperti apa Bawaslu Kabupaten Pamekasan melaksanakan tupoksinya sebagai lembaga yang mengawasi jalannya Pemilu.

Teknik sampling yang dilakukan adalah purposive sampling, yaitu pengambilan sampel berdasarkan pertimbangan tertentu yang disesuaikan dengan tujuan pokok atau fokus penelitian yang sedang dilakukan (Moleong, 2015: 224-225). Artinya, data penelitian harus didapatkan dari sumber yang mempunyai atau menguasai langsung data yang dibutuhkan oleh peneliti. Dalam hal ini, Ketua Bawaslu Kabupaten Pamekasan sebagai narasumber utama yang diwawancarai, dan Anggota Bawaslu (Koordinator Divisi Hukum, Data dan Informasi) Kabupaten Pamekasan sebagai penanggung jawab segala dokumentasi kerja Bawaslu Kabupaten Pamekasan dalam mengawasi dan menangani pelanggaran pada Pemilu 2019.

\section{HASIL DAN PEMBAHASAN}

\section{Wewenang Bawaslu Kabupaten Pamekasan}

Dalam menangani pelanggaran Pemilu, Bawaslu Kabupaten Pamekasan memiliki wewenang untuk menindaklanjuti pelanggaran dari dua sumber. Pertama, pelanggaran yang bersifat temuan. Temuan adalah pelanggaran Pemilu yang ditemukan berdasarkan hasil pengawasan Bawaslu Kabupaten Pamekasan beserta jajarannya. Pelanggaran ini wajib ditindak oleh Bawaslu Kabupaten Pamekasan, meskipun tidak ada yang melapor (Saidi, 2019: 60). Secara definitif pelanggaran yang bersifat temuan telah dijelaskan dalam Pasal 4 ayat 2 Peraturan Badan Pengawas Pemilihan Umum (Perbawaslu) Nomor 7 Tahun 2018 Tentang Penanganan Temuan dan Laporan Pelanggaran Pemilu, "Hasil pengawasan sebagaimana dimaksud pada ayat (1) yang terdapat dugaan pelanggaran Pemilu disampaikan dan 
diputuskan dalam rapat pleno Bawaslu, Bawaslu Provinsi, Bawaslu Kabupaten/Kota, Panwaslu Kecamatan, atau Panwaslu LN sebagai Temuan dugaan pelanggaran yang dituangkan dalam formulir model B.2" (Perbawaslu 7, 2018: 7).

Kedua. Palanggaran yang bersifat laporan. Laporan adalah dugaan pelanggaran Pemilu yang dilaporkan masyarakat kepada Bawaslu Kabupaten Pamekasan dan jajarannya. Bawaslu Kabupaten Pamekasan wajib menindaklanjuti setiap laporan masyarakat dan memberitahukan kepada masyarakat (pelapor) terkait status laporan tersebut setelah selesai ditangani (Saidi, 2019: 60). Secara definitif pelanggaran yang bersifat laporan telah dijelaskan dalam Pasal 8 ayat (1) Perbawaslu Nomor 7 Tahun 2018 Tentang Penanganan Temuan dan Laporan Pelanggaran Pemilu, "Laporan yang diterima secara langsung di Kantor Pengawas Pemilu yang dituangkan dalam formulir model B.1” (Perbawaslu 7, 2018: 8).

Terkait jenis pelanggarannya sendiri ada empat macam. Pertama, pelanggaran administrasi. Merupakan pelanggaran terhadap tatacara, prosedur, atau mekanisme yang berkaitan dengan administrasi pelaksanaan Pemilu dalam setiap tahapan penyelenggaraan Pemilu. Kedua, pelangaran tindak pidana Pemilu. Merupakan segala tindakan yang berhubungan dengan pelaksanaan Pemilu yang melanggar ketentuan pidana Pemilu dalam peranturan perundang-undangan. Ketiga, pelanggaran kode etik penyelenggara Pemilu. Merupakan pelanggaran terhadap etika penyelenggara Pemilu yang berdasarkan sumpah dan/atau janji sebelum menjalankan tugas sebagai penyelenggara Pemilu. Keempat, pelanggaran hukum lainnya. Merupakan pelanggaran yang berhubungan dengan Pemilu namun bukan pelanggaran Pemilu sebagaimana ditetapkan dalam Undang-undang Pemilu. Terhadap pelanggaran hukum lainnya ini, Bawaslu Kabupaten Pamekasan meneruskan kepada instansi atau pihak yang berwenang (Saidi, 2019: 7-8).

\section{Penanganan Pelanggaran Pemilu 2019 Di Kabupaten Pamekasan}

Secara keseluruhan temuan dan laporan penanganan pelanggaran Pemilu 2019 yang ditangani oleh Bawaslu Kabupaten Pamekasan tertera di dalam tabel di bawah ini.

Tabel 1: Temuan dan Laporan Penanganan Pelanggaran Pemilu 2019

\begin{tabular}{|c|c|c|c|c|c|c|c|c|}
\hline \multicolumn{3}{|c|}{$\begin{array}{c}\text { Sumber } \\
\text { Penanganan Pelanggaran }\end{array}$} & \multicolumn{6}{|c|}{ Jenis Pelanggaran } \\
\hline \multirow[b]{2}{*}{ Temuan } & \multirow[b]{2}{*}{ Laporan } & \multirow[b]{2}{*}{ Jumlah } & \multicolumn{3}{|c|}{ Administrasi (Adm) } & \multirow[b]{2}{*}{ Pidana } & \multirow[b]{2}{*}{ Etik } & \multirow[b]{2}{*}{$\begin{array}{c}\text { Hukum } \\
\text { lainya }\end{array}$} \\
\hline & & & $\begin{array}{l}\text { Adm } \\
\text { APK }\end{array}$ & $\begin{array}{l}\text { Adm } \\
\text { Non } \\
\text { APK }\end{array}$ & $\begin{array}{c}\text { Jumlah } \\
\text { Adm }\end{array}$ & & & \\
\hline 185 & 22 & 207 & 182 & 15 & 197 & 8 & 1 & 1 \\
\hline
\end{tabular}

Sumber: Bawaslu Kabupaten Pamekasan

Secara keseluruhan penanganan pelanggaran Pemilu 2019 yang ditangani oleh Bawaslu Kabupaten Pamekasan bersumber dari 185 temuan dan 22 laporan masyarakat. Dari 
jenis pelanggarannya terbanyak adalah pelanggaran administrasi 197 pelanggaran. Pelanggaran administrasi tersebut terbagi ke dalam pelanggaran pemasangan Alat Peraga Kampanye (APK) 182 pelanggaran (pemasangan APK yang masuk katagori melanggar yaitu; dipasang di tempat yang dilarang (tempat ibadah, tempat pendidikan, rumah sakit, gedung milik pemerintah, jalan protokol, jalan bebas hambatan, sarana-prasarana publik, di paku di pohon) dan berisi materi yang dilarang (mempersoalkan dasar negara Pancasila dan UUD 1945, melakukan kegiatan yang membahayakan NKRI, menghina seseorang berdasarkan SARA, menghasut dan mengadu domba, mengancam, menjanjikan uang atau materi kepada masyarakat) dan pelanggaran administrasi selain APK 15 pelanggaran. Pelanggaran pidana Pemilu 8 (delapan). Pelanggaran etik penyelenggara Pemilu ada 1 (satu). Pelanggaran Pemilu hukum lainnya ada 1 (satu).

\section{Temuan Pelanggaran Pemilu}

Bawaslu Kabupaten Pamekasan beserta jajarannya menangani sebanyak 185 temuan dugaan pelanggaran Pemilu. Dari 185 temuan ini, mayoritas adalah dugaan pelanggaran pemasangan APK 182 dugaan pelanggaran. Setelah dikaji, 182 dugaan pelanggaran pemasangan APK tersebut semuanya terbukti melanggar dan dilakukan penertiban oleh Bawaslu Kabupaten Pamekasan beserta jajarannya dengan bantuan aparat Satpol PP Kabupaten Pamekasan dan jajaran aparat keamanan. Penertiban APK ini dilakukan sejak sebelum masa kampanye, saat masa kampanye, hingga hari tenang pelaksanaan Pemilu 2019. 182 pelanggaran APK ini tersebar di 13 kecamatan antara lain; Kecamatan Pamekasan 28 pelanggaran, Kecamatan Tlanakan 20 pelanggaran, Kecamatan Proppo 2 pelanggaran, Kecamatan Palengaan 6 pelanggaran, Kecamatan Waru 5 pelanggaran, Kecamatan Batumarmar 17 pelanggaran, Kecamatan Pasean 12 pelanggaran, Kecamatan Kadur 9 pelanggaran, Kecamatan Pakong 7 pelanggaran, Kecamatan Pegantenan 11 pelanggaran, Kecamatan Larangan 24 pelanggaran, Kecamatan Galis 24 pelanggaran, Kecamatan Pademawu 17 pelanggaran.

Untuk tiga temuan dugaan pelanggaran lainnya yaitu 2 (dua) temuan pelanggaran administrasi non APK dan 1 (satu) temuan dugaan pelanggaran tindak pidana Pemilu. Dua temuan dugaan pelanggaran administrasi Pemilu 2019 adalah, pertama, kelalaian KPU Kabupaten Pamekasan dalam memfasilitasi APK bagi peserta Pemilu. Dalam kebijakan Pemilu 2019, KPU Kabupaten Pamekasan memiliki kewajiban memfasilitasi/ membuatkan APK untuk peserta Pemilu (selain APK yang dibuat sendiri oleh peserta Pemilu), berdasarkan desain APK yang telah disetorkan sebelumnya oleh peserta Pemilu kepada KPU Kabupaten Pamekasan. APK fasilitasi KPU ini harus selesai sebelum masa kampanye dimulai. Masa kampanye dimulai pada 23 September 2018 hingga 13 April 2019. Namun hingga 23 September 2018, KPU Kabupaten Pamekasan belum menyerahkan APK fasilitasi kepada peserta Pemilu, sehingga peserta Pemilu dirugikan.

Bawaslu Kabupaten Pamekasan menangani perkara ini, dengan memeriksa Ketua, Anggota KPU dan Sekretaris KPU Kabupaten Pamekasan, serta beberapa pihak terkait lainya. Setelah berkas pemeriksaan lengkap, diajukan ke Bawaslu Provinsi Jawa Timur 
untuk disidangkan. Sidang pemeriksaan dilakukan di Kantor Bawaslu Provinsi Jawa Timur, dihadiri Bawaslu Kabupaten Pamekasan dan KPU Kabupaten Pamekasan serta para saksi dari perkara ini. Berdasarkan putusan Majelis Pemeriksa Bawaslu Provinsi Jawa Timur Nomor: 04/TM/PP/ADM/PROV/16.00/XII/2018 Tanggal 20 Desember 2018 dinyatakan bahwa Ketua, Anggota KPU dan Sekretaris KPU Kabupaten Pamekasan terbukti melakukan perbuatan pelanggaran administrasi Pemilu, dengan diberikan sanksi berupa teguran tertulis.

Kedua, temuan dugaan pelanggaran kampanye Pemilu 2019 di media massa di luar jadwal yang ditentukan oleh peraturan perundang-undangan. Ditemukan dua orang Calon Legislatif (Caleg) DPRD Kabupaten Pamekasan, masing-masing dari Partai Nasdem dan PAN yang mengiklankan dirinya di salah satu media massa on-line sebelum masa kampanye media massa berlaku. Kampanye media massa Pemilu 2019 berlaku Tanggal 24 Maret hingga 13 April 2019. Bawaslu Kabupaten Pamekasan memeriksa kedua orang Caleg tersebut, manajemen dari media massa on-line bersangkutan, serta beberapa pihak terkait lainya. Setelah berkas pemeriksaan lengkap, diajukan ke Bawaslu Provinsi Jawa Timur untuk disidangkan. Sidang pemeriksaan dilakukan, dan berdasarkan putusan Majelis Pemeriksan Bawaslu Provinsi Jawa Timur Nomor: 11/TM/PL/ADM/PROV/16.00/I/2019 Tanggal 24 Januari 2019 dinyatakan kedua Caleg tersebut terbukti melakukan perbuatan pelanggaran administrasi Pemilu, memberikan teguran tertulis, dan memerintahkan kepada KPU Kabupaten Pamekasan untuk mengurangi atau tidak melibatkan kedua Caleg bersangkutan selama tiga hari masa/tahapan penayangan iklan kampanye selama 21 hari sebelum dimulainya masa tenang.

Satu temuan lainnya yaitu dugaan pelanggaran pidana Pemilu 2019. Dimana saat pelaksanaan acara kerapan sapi piala Presiden pada Bulan Oktober 2018 di Stadion R. Soenarto Hadiwidjojo Pamekasan, yang diselenggaran oleh Barkorwil Pamekasan terdapat unsur kampanye. Pembawa acara kegiatan ini saat memandu acara sempat mengampanyekan salah satu Caleg DPR RI Dapil Madura yang merupakan warga Kabupaten Pamekasan. Bawaslu menjadikan ini temuan mengacu kepada pasal 547 Undang-undang Nomor 7/2017 Tentang Pemilu bahwa, "Setiap pejabat negara yang dengan sengaja membuat keputusan dan atau melakukan tindakan yang menguntungkan atau merugikan salah satu peserta Pemilu dalam masa kampanye, dipidana dengan pidana penjara paling lama tiga tahun dan denda paling banyak Rp 36.000.000" (UndangUndang Pemilu, 2018: 260). Maksudnya adalah, ketua panitia dari kegiatan ini adalah Kepala Bakorwil Pamekasan, yang merupakan seorang pejabat negara. Sehingga yang bertanggung jawab atas segala tindakan pada pelaksanaan kerapan sapi piala Presiden tersebut adalah ketua panitia, termasuk tindakan pembawa acara saat mengkampanyekan salah satu Caleg.

Untuk menangani perkara tindak pidana Pemilu, sebagaimana dalam Perbawaslu Nomor 31/ 2018 Tentang Sentra Penegakan Hukum Terpadu (Gakkumdu) Pasal 5 Ayai 1, 
Bawaslu Kabupaten Pamekasan harus melibatkan kepolisian (Penyidik Polres Pamekasan) dan kejaksaan (Jaksa Penuntut Umum Kejaksaan Negeri Pamekasan) (Perbawaslu 31, 2018: 7). Sentra Gakkumdu telah memeriksa sejumlah pihak yang berhubungan dengan kegiatan tersebut. Setelah dilakukan kajian bersama antara Bawaslu, kepolisian, dan kejaksaan, disimpulkan bahwa temuan ini tidak memenuhi unsur tindak pidana Pemilu dan tidak dapat dilanjutkan ke tahap penyidikan. Alasannya, karena yang diduga melakukan kampanye dalam acara tersebut adalah pembawa acara yang dikontrak oleh panitia. Dimana pembawa acaranya adalah bukan Aparatur Sipil Negara (ASN) apalagi pejabat negara.

2. Laporan Pelanggaran Pemilu

Bawaslu Kabupaten Pamekasan menangani sebanyak 22 laporan dugaan pelanggaran Pemilu 2019. Dari 22 laporan tersebut terdiri dari 13 laporan dugaan pelanggaran administrasi Pemilu, 7 (tujuh) laporan dugaan pelanggaran pidana Pemilu, 1 (satu) laporan dugaan pelanggaran kode etik penyelenggara Pemilu, dan 1 (satu) lapora dugaan pelanggaran Pemilu hukum lainnya.

Dugaan pelanggaran administrasi Pemilu 2019 dari 13 laporan tersebut, terbagi ke dalam dua pola penanganan. 8 (delapan) laporan ditangani menggunakan mekanisme menurut Perbawaslu Nomor 7/2018 Tentang Penanganan Temuan dan Laporan Pelanggaran Pemilu (tidak perlu melalui sidang pemeriksaan oleh majelis pemeriksa Bawaslu Kabupaten Pamekasan), dan 5 (lima) laporan ditangani menggunakan mekanisme menurut Perbawaslu Nomor 8/2018 Tentang Penyelesaian Pelanggaran Administratif Pemilu (melalui sidang pemeriksaan oleh mejelis pemeriksa Bawaslu Kabupaten Pamekasan) (Perbawaslu 8, 2018: 9).

Delapan laporan dugaan pelanggaran administrasi Pemilu masuk ke Bawaslu Kabupaten Pamekasan antara akhir April hingga awal Mei 2019, yaitu disaat proses rekapitulasi suara hasil Pemilu 2019 tingkat Kabupaten Pamekasan.

Laporan berasal dari beberapa Daerah Pemilihan (Dapil). Pertama, Dapil 1 (Kecamatan Pamekasan dan Kecamatan Tlanakan). Ada 4 (empat) laporan. Semuanya terkait perbedaan hasil rekapitulasi suara sejumlah Caleg DPRD Kabupaten Pamekasan di tingkat kecamatan antara saksi Parpol dengan PPK. Setelah Bawaslu Kabupaten Pamekasan melakukan kajian, mengeluarkan rekomendasi kepada KPU Kabupaten Pamekasan pada saat rekapitulasi suara tingkat Kabupaten Pamekasan untuk melakukan perbaikan rakapitulasi suara di Dapil 1, berdasarkan catatan-catatan dari Bawaslu Kabupaten Pamekasan. Setelah dilakukan perbaikan, meskipun ada perubahan perolehan suara Caleg DPRD Kabupaten Pamekasan namun tetap tidak merubah porsi dan posisi kursi Calon Anggota DPRD Kabupaten Pamekasan di Dapil 1.

Kedua, 2 (dua) laporan dari Dapil 4 (Kecamatan Kadur, Kecamatan Pakong, dan Kecamatan Pegantenan). Terkait perbedaan hasil rekapitulasi suara sejumlah Caleg DPRD Kabupaten Pamekasan di tingkat kecamatan antara saksi Parpol dengan PPK. Setelah Bawaslu Kabupaten Pamekasan melakukan kajian, mengeluarkan rekomendasi 
kepada KPU Kabupaten Pamekasan pada saat rekapitulasi suara tingkat Kabupaten Pamekasan untuk melakukan perbaikan rakapitulasi suara di Dapil 4, berdasarkan catatan-catatan dari Bawaslu Kabupaten Pamekasan. Setelah dilakukan perbaikan, meskipun ada perubahan perolehan suara Caleg DPRD Kabupaten Pamekasan namun tetap tidak merubah porsi dan posisi kursi Calon Anggota DPRD Kabupaten Pamekasan di Dapil 4.

Ketiga, 2 (dua) laporan dari Dapil 5 (Kecamatan Pademawu, Kecamatan Galis, dan Kecamatan Larangan). Modus laporannya sama dengan dua Dapil sebelumnya, yaitu perbedaan hasil rekapitulasi suara sejumlah Caleg DPRD Kabupaten Pamekasan di tingkat kecamatan antara saksi Parpol dengan PPK. Setelah Bawaslu Kabupaten Pamekasan melakukan kajian, mengeluarkan rekomendasi kepada KPU Kabupaten Pamekasan pada rekapitulasi suara tingkat Kabupaten Pamekasan untuk melakukan perbaikan rakapitulasi suara di Dapil 5, berdasarkan catatan-catatan dari Bawaslu Kabupaten Pamekasan. Setelah dilakukan perbaikan, terjadi perubahan satu posisi kursi Calon Anggota DPRD Kabupaten Pamekasan. Caleg yang awalnya unggul suara dari Caleng yang lain, setelah keluar rekomendasi dari Bawaslu Kabupaten Pamekasan, menjadi berbalik yaitu kalah dari Caleng lain tersebut.

Selanjutnya, untuk penanganan 5 (lima) laporan dugaan pelanggaran administrasi Pemilu yang ditangani menggunakan mekanisme sidang pemeriksaan oleh mejelis Pameriksa Bawaslu Kabupaten Pamekasan, antara lain; pertama, laporan yang masuk pada Bulan September 2018 kepada Bawaslu Kabupaten Pamekasan dengan terlapor KPU Kabupaten Pamekasan. Terkait Daftar Calon Tetap (DCT) Caleg DPRD Kabupaten Pamekasan yang ditetapkan oleh KPU Kabupaten Pamekasan. Menurut pelapor, KPU Kabupatean Pamekasan melakukan pelanggaran administrasi Pemilu karena meloloskan dua Caleg yang masih aktif sebagai pendamping desa. Setelah laporan ini dikaji oleh majelis pemeriksa, diputuskan dalam Putusan Pendahuluan Majelis Pemeriksa Bawaslu Kabupaten Pamekasan Nomor: 01/LP/ADM/KAB/16.28/IX/2018 Tanggal 9 Oktober 2018 dinyatakan bahwa laporan tersebut diregister (memenuhi syarat formil dan materiil) dan dilanjutkan dengan sidang Pemeriksaan.

Sidang pemeriksaan dilakukan oleh Majelis Pemeriksa Bawaslu Kabupaten Pamekasan. Sidang dilakukan sebanyak lima kali, dimulai dari pembacaan laporan oleh pelapor dan jawaban/ tanggapan oleh terlapor, pembuktian (pemeriksaan bukti-bukti dan saksi-saksi), permintaan keterangan pihak-pihak/ lembaga terkait, kesimpulan pihak pelapor dan terlapor, dan terakhir pembacaan putusan oleh majelis pemeriksa. Setelah mengamati fakta-fakta dalam sidang pemeriksaan dan kajian mejelis pemeriksa, Majelis Pameriksa dalam Putusan Nomor: 01/LP/PL/ADM/KAB/16.28/IX/2018 memberikan kesimpulan bahwa pendamping desa tidak sama dengan BUMN/ BUMD yang wajib mengundurkan diri jika mencalonkan sebagai anggota DPRD pada saat penetapan DCT, bahwa pendamping desa tidak termasuk objek yang wajib mengundurkan diri sebagaimana disebutkan dalam Surat Edaran KPU RI Nomor: 
748/PL.014.SD/06/KPU/VII/2018 perihal wajib pengunduran diri, bahwa KPU Kabupaten Pamekasan telah melaksanakan mekanisme atau prosedur sebagaimana yang dimandatkan oleh peraturan perundang-undangan yang berlaku. Sehingga dinyatakan bahwa laporan tidak terbukti secara sah dan meyakinkan melakukan perbuatan pelanggaran administrasi Pemilu.

Selanjutnya, untuk 4 (empat) laporan lainnya, hasil kajian majelis pemeriksa menyatakan semuanya hanya sampai pada putusan pendahuluan, yang artinya bahwa laporan dugaaan pelanggaran administrasi Pemilu tidak dapat diterima dan laporan tersebutu tidak ditindaklanjuti dengan sidang pemeriksaan. Laporan kedua, masuk di Bulan April, bahwa semua KPPS di Kecamatan Proppo, Kecamatan Palengaan, dan Kecamatan Pegantenan, tidak menempelkan C1 Plano DPRD Provinsi dan DPR RI di setiap desa dihampir seluruh kecamatan. Putusan Pendahuluan Majelis Pemeriksa Bawaslu Kabupaten Pamekasan Nomor: 05/LP/PL/ADM/KAB/16.28/IV/2019 Tanggal 13 Mei 2019 memberikan kesimpulan bahwa laporan KPPS tidak mengumumkan C1 Plano DPR Provinsi dan DPR RI, sedangkan dalam Peraturan KPU Nomor 3 Tahun 2019 Tentang Pemungutan dan Penghitungan Suara Dalam Pemilihan Umum, "KPPS hanya memiliki kewajiban untuk mengumumkan salinan formulir Model C-KPU, Model C1PPWP, Model C1-DPR, Model C1-DPD, Model C1-DPRD Provinsi, dan Model C1DPRD Kabupaten/Kota di lingkungan TPS yang mudah diakses oleh publik selama 7 (tujuh) Hari".

Ketiga, laporan masuk di Bulan Mei, bahwa diduga terjadi pergeseran suara Caleg DPRD Kabupaten Pamekasan dari salah satu partai ke partai lainnya, diduga dilakukan ole KPU Kabupaten Pamekasan. Putusan Pendahuluan Nomor: 06/LP/PL/ADM/KAB/16.28/V/2019 Tanggal 20 Mei 2019, memberikan kesimpulan bahwa laporan terkait adanya pergeseran suara di salah satu Parpol, Bawaslu Kabupaten Pamekasan telah merekomendasi kepada KPU Kabupaten Pamekasan untuk melakukan pencocokkan terhadap Form C1 dengan From DAA1 Kecamatan Larangan sesuai dengan laporan saksi salah satu Parpol saat rekapitulasi suara tingkat Kabupaten Pamekasan. Selain itu, KPU Kabupaten Pamekasan telah melakukan pencocokkan terhadap C1 dengan DAA1 maka terdapat perubahan di DAA1 sesuai dengan rekomendasi Bawaslu Kabupaten Pamekasan atas laporan masyarakat ke Kantor Bawaslu Kabupaten Pamekasan saat tahapan rekapitulasi suara tingkat Kabupaten Pamekasan.

Keempat, laporan yang juga masuk di Bulan Mei 2019, bahwa diduga terjadi pergeseran suara di internal salah satu Parpol untuk DPR RI pada model DA1 DPR RI di Kecamatan Tlanakan dan Kecamatan Pademawu. Putusan Pendahuluan Nomor: 07/LP/PL/ADM/KAB/16.28/V/2019 Tanggal 27 Mei 2019 memberikan kesimpulan bahwa laporan ini kabur (obscuur libel) atau tidak jelas disebabkan salah satu alat bukti DA1-DPR yang diajukan pelapor tidak ada stempel dari PPK setempat sehingga tidak bisa dijadikan dasar hukum. 
Terakhir, kelima, laporan yang juga masuk di Bulan Mei 2019, bahwa terjadi perbedaan jumlah angka/ suara yang tertera di form C1 se-Desa Buddagan Kecamatan Pademawu dengan data yang ada di DA1 untuk suara perolehan salah satu Parpol, dan terjadi penambahan suara salah satu Parpol untuk DPRD Provinsi, diduga dilakukan PPK Kecamatan Pademawu/ KPU Kabupaten Pamekasan. Putusan Pendahuluan Nomor: 08/LP/PL/ADM/KAB/16.28/V/2019 Tanggal 27 Mei 2019 memberikan kesimpulan bahwa permohonan pelapor terkait penghitungan ulang berdasarkan C1 Plano TPS tidak bisa dilakukan karena sudah melebihi batas waktu, berdasarkan Pasal 74 ayat (2) Peraturan KPU Nomor 9/2019 Tentang Perubahan Peraturan KPU Nomor 3/2019 Tentang Pemungutan dan Penghitungan Suara Pemilu, "Penghitungan suara ulang di TPS sebagaimana dimaksud pada ayat (1) dilaksanakan paling 5 (lima) hari setelah hari dan tanggal pemungutan suara berdasarkan keputusan PPK". Bahwa Bawaslu Kabupaten Pamekasan juga tidak bisa memberikan rekomendasi untuk melakukan perbaikan disebabkan proses rekapitulasi tingkat kabupaten sudah selesai,

Untuk penanganan laporan dugaan pelanggaran tindak pidana Pemilu, Bawaslu Kabupaten Pamekasan menangani 7 (tujuh) laporan antara lain; pertama, laporan masuk di Bulan April 2019, bahwa beredar rekaman suara adanya penyelenggara Pemilu yaitu oknum PPK yang diduga menerima sejumlah uang untuk memenangkan salah satu Caleg DPRD Kabupaten Pamekasan (diduga melanggar Pasal 532 Undang-Undang Pemilu). Hasil kajian Gakkummdu, disimpulkan bahwa buktinya masih lemah, bukti rekaman belum jelas atau rekaman tersebut belum A1 masih katanya-katanya, keberadaannya belum jelas terkait penerima uang oleh oknum PPK sehingga tidak dapat ditindak lanjuti. Kedua, laporan masuk di Bulan Mei 2019, bahwa diduga terjadi penggelembungan data DPT dikarenakan orang yang sudah meninggal masih tercatat (hadir) di salah satu TPS yang diduga dilakukan oleh oknum KPPS dan PPS setempat (diduga melanggar Pasal 505 Undang-Undang Pemilu). Hasil kajian Gakkummdu, setelah melakukan klarifikasi kepada pelapor, terlapor, saksi-saksi, dan pemeriksaan bukti-bukti (penyelidikan), disimpulkan bahwa laporan ini bukti-buktinya kurang kuat, tidak memenuhi unsur tindak pidana dimaksud karena pelapor tidak dapat memberikan alat bukti surat berupa keterangan kematian, sehingga tidak dapat ditindaklanjuti ke penanganan selanjutnya.

Ketiga, laporan yang juga masuk di Bulan Mei 2019, bahwa diduga salah satu PPK mengeluarkan DAA1 dan DA1 (hasil rekapitulasi suara tingkat desa dan tingkat kecamatan) ganda (diduga melanggar Pasal 505 Undang-Undang Pemilu). Hasil penyelidikan Gakkummdu, laporan ini tidak memenuhi unsur tindak pidana dimaksud disebabkan DAA1 dan DA1 yang dimasksud pelapor sudah diperbaiki pada saat rekapitulasi ditingkat Kabupaten Pamekasan. Keempat, laporan yang juga masuk di Bulan Mei 2019, bahwa terdapat ketidaksesuaian antara DAA1 dan DA1 perolehan salah satu partai dengan suara sah di C1 di sejumlah desa di salah satu kecamatan diduga hal tersebut sengaja dirubah dan diduga pelakunya adalah oknum PPK setempat (diduga melanggar Pasal 505 Undang-Undang Pemilu). Hasil penyelidikan Gakkummdu, laporan 
ini tidak bisa ditindaklanjuti ke tahap selanjutnya disebabkan tidak memenuhi unsur tindak pidana Pemilu dimaksud karena bukti dan saksi kurang kuat.

Kelima, laporan yang juga masuk di Bulan Mei 2019, bahwa diduga terjadi penggelembungan suara di beberapa partai politik di sejumlah desa di salah satu kecamatan diduga dilakukan oleh oknum KPPS, PPS dan PPK setempat (diduga melanggar Pasal 505 Undang-Undang Pemilu). Hasil penyelidikan Gakkummdu, laporan ini tidak bisa ditindaklanjuti ke tahap selanjutnya disebabkan tidak memenuhi unsur tindak pidana Pemilu dimaksud karena bukti dan saksi kurang kuat. Keenam, laporan yang juga masuk di Bulan Mei 2019, bahwa terjadi pergeseran suara antar caleg dan penggelembungan suara di sejumlah desa di salah satu kecamatan diduga dilakukan oleh oknum PPK setempat (diduga melanggar Pasal 505 Undang-Undang Pemilu). Hasil penyelidikan Gakkummdu, disimpulkan bahwa tidak memenuhi unsur tindak Pemilu dimaksud karena bukti-bukti kurang kuat. Terakhir, ketujuh, laporan yang juga masuk di Bulan Mei 2019, bahwa ditemukan formulir DA1 beberapa versi di dua kecamatan diduga dilakukan oleh oknum PPK di dua kecamatan tersebut (diduga melanggar Pasal 551 Undang-Undang Pemilu). Hasil penyelidikan Gakkummdu, disimpulkan bahwa unsur tindak pidana Pemilu dimaksud tidak terpenuhi karena sudah ada perubahan/perbaikan saat rekapitulasi suara tingkat kabupaten, dan bukti-bukti kurang kuat.

Penanganan pelanggaran berikutnya yang berasal dari laporan adalah dugaan pelanggaran kode etik penyelenggara Pemilu 2019. Satu laporan masuk ke Bawaslu Kabupaten Pamekasan pada Bulan April 2019. Dilaporkan bahwa Ketua KPPS salah satu TPS di salah satu desa di Kecamatan Pamekasan tetap mengirimkan form-C6 (undangan/ surat pemberitahuan pemungutan suara) padahal pelapor telah mengajukan pindah memilih dan sudah mendapatkan bukti model A5 dari KPU Kabupaten Pamekasan. Atas laporan ini diduga Ketua KPPS tidak profesional dalam bekerja sebagai penyelenggara Pemilu. Terhadap laporan ini, setelah dikaji oleh Bawaslu Kabupaten Pamekasan, merekomendasikan KPU Kabupaten Pamekasan untuk menindaklanjuti pelanggaran kode etik (tidak professionalnya Ketua KPPS dimaksud dalam laporan). KPU Kabupaten Pamekasan memberikan teguran tertulis kepada Ketua KPPS tersebut.

Terakhir dari penanganan pelanggaran Bawaslu Kabupaten Pamekasan, laporan penanganan dugaan pelanggaran hukum lainnya yang masuk pada Bulan April 2019. Satu laporan masuk ke Kantor Bawaslu Kabupaten Pamekasan, bahwa diduga salah satu Kapolsek pada sebuah pertemuan tertutup dengan masyarakat di wilayahnya, dalam sambutannya mengarah kepada mendiskreditkan salah satu pasangan calon PresidenWakil Presiden yang akan berlaga pada Pemilu 2019. Perilaku ini dianggap bertentangan dengan sikap netralitas anggota TNI-Polri. Terhadap laporan ini, Bawaslu Kabupaten Pamekasan melakukan klarifikasi kepada pelapor, terlapor, saksi-saksi dan pemeriksaan bukti-bukti (klarifikasi). Hasil kajian menunjukkan bahwa perkara ini masuk katagori 
pelanggaran hukum lainnya, sehingga Bawaslu Kabupaten Pamekasan meneruskan kepada instansi terkait yaitu Komisi Kode Etik Polri di Mabes Polri Jakarta.

Pemaparan hasil penelitian di atas menunjukkan kinerja Bawaslu Kabupaten Pamekasan dalam menangani pelanggaran Pemilu di Kabupaten Pamekasan selama tahapan Pemilu 2019. Sebagaimana disinggung di awal dalam tulisan ini, bahwa ini kali pertama (Pemilu 2019, Red.) Bawaslu Kabupaten Pamekasan "unjuk gigi” setelah ditetapkan sebagai lembaga permanen. Semangat memermanenkan pengawas Pemilu ad hoc Panwaslu Kabupaten/ Kota menjadi Bawaslu Kabupaten/ Kota yang sudah sejajar dengan KPU Kabupten/ Kota diharapkan dapat memberikan kontribusi yang baik berupa peningkatan kualitas demokrasi khususnya di Kabupaten Pamekasan (Pujiatmiko, 2020: 145).

Terkait penanganan pelanggaran Pemilu 2019 oleh Bawaslu Kabupaten Pamekasan ini, dapat dikatakan telah mewujudkan keadilan dalam pelaksanaan Pemilu 2019 di Kabupaten Pamekasan. Hal ini dapat dilihat pertama, tidak "pandang bulunya" Bawaslu Kabupaten Pamekasan dalam menertibkan setiap APK yang melanggar. Sejumlah APK milik peserta Pemilu, baik yang incumbent maupun yang baru mencalonkan diri, mulai dari Pemilu Presiden-Wakil Presiden, Pemilu DPR, DPD, DPRD Provinsi, dan DPRD Kabupaten Pamekasan tidak luput dari penertibannya yang dilakukan dalam 2 (dua) minggu sekali selama masa kampanye berlangsung hingga hari tenang. Total ada 182 titik APK melanggar yang ditertibkan, dengan barang bukti APK sekitar 600 buah dari berbagai ukuran, mulai ukuran terkecil yang dipaku di pohon-pohon hingga ukuran terbesar yang terpasang di Billboard/ papan reklame yang pemasangannya berbayar di jalan-jalan protokol. Hal ini dalam rangka memberikan rasa adil, bahwa kampanye bisa dilakukan oleh siapa saja dan dimana saja selama tidak melanggara aturan yang ada. Kampanye tidak hanya untuk yang memiliki modal banyak sehingga bisa membuat APK yang banyak dan besar lantas dipasang seenaknya bahkan di tempat yang berbayar, asalkan yang bersangkutan bisa populer lewat media APK tersebut.

Kedua, temuan dan laporan lainnya ditangani dengan professional oleh Bawaslu Kabupaten Pamekasan. Segala perilaku yang merupakan pelanggaran dalam tahapan Pemilu 2019 ditanganinya, apakah itu penyelenggara Pemilu, peserta Pemilu, bahkan Polri yang harus netral, yang merupakan mitra Bawaslu Kabupaten Pamekasan dalam Gakkumdu, ketika ada laporan oknum Polri di Kabupaten Pamekasan yang diduga tidak netral maka Bawaslu Kabupaten Pamekasan tetap memprosesnya sesuai dengan aturan dan prosedur yang ada. Salah satu yang menonjol dari penanganan pelanggaran oleh Bawaslu Kabupaten Pamekasan ini, dari rekomendasinya yang bersifat wajib itu bisa menggugurkan satu tiket kursi Calon Anggota DPRD Kabupaten Pamekasan diganti oleh Calon Anggota DPRD Kabupaten Pamekasan lainnya, karena terbukti Calon yang gugur tersebut telah melakukan manipulasi suara.

Bawaslu Kabupaten Pamekasan juga telah melibatkan Rakyat/ masyarakat Kabupaten Pamekasan dengan baik dan maksimal dalam mengawal dan mengawasi setiap tahapan Pemilu 2019. Ini terlihat dari laporan masyarakat yang masuk ke Bawaslu Kabupaten 
Pamekasan selama tahapan Pemilu 2019. Laporan masyarakat tentang dugaan pelanggaran Pemilu lebih banyak daripada temuan Bawaslu Kabupaten Pamekasan sendiri. Bawaslu Kabupaten Pamekasan hanya menemukan 3 (tiga) betuk pelanggaran (selain temuan pelanggaran APK), sedangkan laporan masyarakat sebanyak 22 laporan. Ini menunjukkan bahwa keterlibatan rakyat Kabupaten Pamekasan sudah cukup bagus dalam ikut mengawasi pelaksanaan Pemilu 2019 di Kabupaten Pamekasan bersama-sama dengan Bawaslu Kabupaten Pamekasan demi adilnya Pemilu di Kabupaten Pamekasan.

\section{KESIMPULAN}

Dalam mengawasi dan menangani pelanggaran Pemilu 2019, Bawaslu Kabupaten Pamekasan telah mewujudkan keadilan Pemilu. Hal ini dapat dilihat pertama, tidak "pandang bulunya" dalam menertibkan setiap APK yang melanggar. Total ada 182 titik APK melanggar yang ditertibkan, dengan barang bukti APK sekitar 600 buah dari berbagai ukuran mulai ukuran terkecil yang dipaku di pohon-pohon hingga ukuran terbesar yang dipasang Billboard/ papan reklame berbayar. Kedua, temuan dan laporan ditangani dengan professional. Segala pelanggaran dalam tahapan Pemilu 2019 ditanganinya, mulai dari penyelenggara Pemilu yang tidak professional, peserta Pemilu yang tidak taat aturan, bahkan aparat yang harus netral, ketika didapati oknum aparat tidak netral maka Bawaslu Kabupaten Pamekasan memprosesnya sesuai aturan dan prosedur.

Bawaslu Kabupaten Pamekasan juga telah melibatkan rakyat/ masyarakat Kabupaten Pamekasan dengan baik dalam ikut mengawasi setiap tahapan Pemilu 2019. Terlihat dari banyaknya laporan masyarakat (22 laporan) yang masuk ke Bawaslu Kabupaten Pamekasan. Ini menunjukkan bahwa keterlibatan rakyat di Kabupaten Pamekasan sudah cukup bagus dalam ikut mengawasi pelaksanaan Pemilu 2019 di Kabupaten Pamekasan bersama-sama dengan Bawaslu Kabupaten Pamekasan demi adilnya Pemilu di Kabupaten Pamekasan.

\section{DAFTAR PUSTAKA}

Alfiantoro, Handoko. (2018). Sentra Penegakan Hukum Terpadu Dalam Konsep Sistem Peradilan Pemilu. Jurnal Adhyasta Pemilu Volume 4 Nomor 2. 135-148.

Hermanto, Jono, dkk. (2020). Pengaruh Isu, Figur, Rekam Jejak Dan Partai Politik Terhadap Partisipasi Pemilih Dalam Pemilihan Presiden (Pilpres) Tahun 2019. Jurnal Reformasi Volume 10 Nomor 1. 27-33.

Moleong, Lexy J. (2015). Metodologi Penelitian Kualitatif. Bandung: PT Remaja Rosdakarya. Cetakan Ke-34.

Perbawaslu Nomor 31 Tahun 2018 Tentang Sentra Penegakan Hukum Terpadu.

Perbawaslu Nomor 7 Tahun 2018 Tentang Penanganan Temuan dan Laporan Pelanggaran Pemilu.

Perbawaslu Nomor 8 Tahun 2018 Tentang Penyelesaian Pelanggaran Administratif Pemilu. Pujiatmiko, Sri Sugeng. (2020). Penanganan Pelanggaran Pemilu; Dalam Teori dan Praktek. Tuban: Karya Litera Indonesia. 
ISSN 2088-7469 (Paper) ISSN 2407-6864 (Online)

Volume 10 Nomor 2 (2020)

Saidi, Abdullah, dkk. (2019). Laporan Komprehensif Hasil Pengawasan Pemilu Tahun 2019. Pamekasan: Bawaslu Kabupaten Pamekasan.

Sukmajati, Mada (Ed.). (2019). Serial Evaluasi Penyelenggaraa Pemilu Serentak 2019; Perihal Pelaksanaan Hak Politik. Jakarta: Bawaslu.

Undang-Undang Nomor (UU) 7 Tahun 2017 tentang Pemilihan Umum (Pemilu).

Zuhro, R. Siti. (2019). Demokrasi dan Pemilu Presiden 2019. Jurnal Penelitian Politik LIPI Volume 16 Nomor 1. 69-81. 